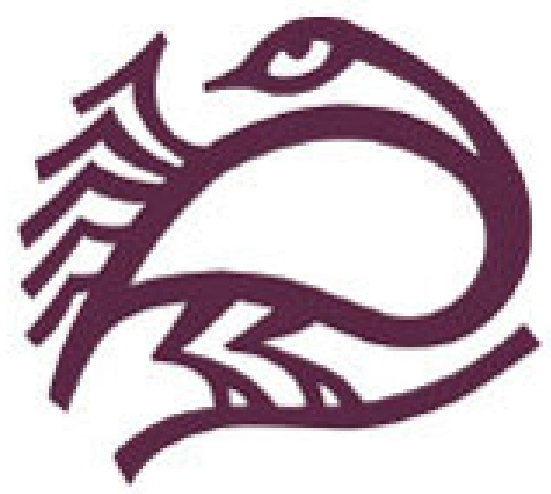

Post-Zionist Critique on Israel and the Palestinians Part III: Popular Culture Author(s): Ilan Pappe

Source: Journal of Palestine Studies, Vol. 26, No. 4 (Summer, 1997), pp. 60-69

Published by: University of California Press on behalf of the Institute for Palestine Studies

Stable URL: http://www.jstor.org/stable/2537907

Accessed: 28/03/2014 10:34

Your use of the JSTOR archive indicates your acceptance of the Terms \& Conditions of Use, available at http://www.jstor.org/page/info/about/policies/terms.jsp

JSTOR is a not-for-profit service that helps scholars, researchers, and students discover, use, and build upon a wide range of content in a trusted digital archive. We use information technology and tools to increase productivity and facilitate new forms of scholarship. For more information about JSTOR, please contact support@jstor.org. 


\title{
Post-Zionist Critique on Israel and the Palestinians Part III: Popular Culture
}

\author{
ILAN PaPpÉ
}

This third and final part of a summary of post-Zionist critique follows the manifestations of new ways of looking at Israeli history and the "other" in film, theater, novels, music, and poetry. Cinema has the greatest potential for influencing the public and has gone further than the other media in challenging traditional views. The author concludes that the cultural products that have seriously transcended the Zionist narrative and its negative portrayal of the Arabs remain outside the Israeli canon and have limited impact, though the groundwork has been laid for what is clearly a growing trend.

POST-Zionist CRITIQUe IN IsRael is primarily part of an elite discourse on the country's identity and history, involving mainly academicians, journalists, and, to a lesser extent, politicians. In recent years, it has also attracted the attention of some educators. Nonetheless, alternative views have also filtered into the popular culture: A significant number of writers, playwrights, and filmmakers share the basic assumptions of the "post-Zionist" scholars. What follows is an attempt to survey manifestations of the post-Zionist critique in the arts, before proceeding to a tentative speculation concerning the impact of the alternative discourse or images on society as a whole.

\section{Post-Zionist Poetry, Pop Music, and Literature}

There is a clear distinction in Israel between fiction and poetry when it comes to post-Zionist ideas. Very few prose writers have crossed the consensual lines or have been willing even to acknowledge that they work within the constraints of an ideological orientation imposed by Zionism. Poets, on the other hand, have found it easier to experiment with alternative viewpoints. The Lebanon War led some of the leading poets to write pacifist or at least antiwar poetry, ${ }^{1}$ and the tendency to decry the evils of the Israeli occupation in poetry continued throughout the intifada. These poems have never been collected in accessible form, but in any case, poetry is not widely read in Israel. One trend worth noting is the translation, since the 1970s, of Iraqi, Lebanese, Palestinian, and Syrian poetry into Hebrew. The literary

Ilan Pappt, professor of political science at Haifa University and academic head of the Institute for Peace Research Givat Haviva, is the author of The Making of the Arab-Israeli Conflict, 1947-1951, among other works. 
monthly Iton 77 began to publish such poems regularly in the 1980s, and even though one can doubt the broader impact of a journal read by a restricted audience, the translations could serve as a factor in shaping scholarly and literary views on reality.

In the domain of mainstream music, few of Israel's pop singers who imitate Western models would risk their relationship with the wider public by being "political." One interesting exception is the pop star Aviv Gefen, among the most popular singers in Israel, whose lyrics contain sharp though simplistic criticism of Israeli militarism; he himself refused to serve in the army when he was called up. Since he is mainly an impresario with productions on a Michael Jackson-type scale, it is the show, not the message, that makes him popular. Still, his continuing appeal does signify a certain change in local tolerance for nonconformist lyrics that may herald a wider acceptance of less nationalistic ideas among the youth.

Arabic music, in contrast, caters to a wider audience. Music from all over the Arab world, ranging from Um Kulthum to $r a^{\prime} i$ with many local versions, is extremely popular in Israel. Unfortunately, music, like food and folklore, cannot be said to be a bridge between Jewish society and the Arab world. The popularity of Arabic music demonstrates a process of appropriation by the political elite of Arab cultural artifacts appealing to a large segment of the population-i.e., the Sephardic Jews. The music has no political or substantial cultural implication for the identity and behavior of the society or state, and the most right-wing parties play it at the very rallies where they preach anti-Arab rhetoric. Even the Gush Emunim radio station energetically broadcasts Arabic music.

In the realm of literature, there has been an increase in recent years in the number of works-mainly Palestinian and Egyptian short stories-translated from Arabic and in the interest shown such works by established publishing houses. The Palestinian stories, which tend to carry a political message, are not bought or distributed widely, however. On the other hand, the translation into Hebrew of the late Emile Habibi's novels, which reconstruct the evil days of the military regime imposed on the Palestinians of Israel until 1966, to an extent exposed the more avant-garde Israeli readers to how Palestinians in Israel view their past and dream about their future.

As for works originally written in Hebrew, so far only a handful have provided anything approaching a new view of Palestinian and Israeli societies. The writers who have are mainly outside the mainstream. Shimon Ballas, for example, was quite famous in Iraq where he had grown up as a communist but is either neglected by mainstream critics in Israel or denigrated as representing a

$A$ self-declared identity as an Arab Jew is bound to be perceived by upholders of Zionism in Israel as betrayal. primitive form of literature. Needless to say, publishing houses follow suit, and Ballas's works, which criticize Zionist or Western orientalism as well as the willingness of Arabs in general to internalize this orientalism, are rejected as unprofitable or as having inadequate cultural value. In his recent book on 
Zionism and Israeli fiction, Yerach Gover comments that Ballas, by presenting himself as an Arab Jew, offers a counternarrative; ${ }^{2}$ a self-declared identity as an Arab Jew is bound to be perceived by genuine or cynical upholders of Zionism in Israel as betrayal. Albert Swisa, of North African origin, can also be said to represent an Arab-Jewish counternarrative. ${ }^{3}$ The most influential writer of this trend is Sami Michael, better known in Israel than Ballas and Swisa and widely read. His main contribution lies in his ability to open for Hebrew readers the local Palestinian perception of the Israeli reality.

A different kind of counternarrative has been provided by the poet Yitzhak Laor in his recent The People, Food Fit for a King, ${ }^{4}$ a novel that uses every possible literary device, from the names and the language of the heroes to the way the plot evolves, to question basic truisms about Israeli society. This story of an army unit about to enter the 1967 war has several endings and butchers more than one sacred Israeli cow. Laor ridicules the sanctity of the army and its heroism on the battlefield and rejects common Israeli notions about genuine friendships forged in wars.

Finally, David Grossman's documentary reports about the Israeli occupation and the status of Palestinians in Israel have presented sights and sounds generally inaccessible to Jews in Israel. ${ }^{5}$ Grossman, unlike the novelists mentioned above, has been high on the bestseller lists for some years; even if he is more mainstream and at times less critical, his wide readership has had a significant impact. These beginnings, however humble, at least have familiarized some readers with another, anti-Zionist, post-Zionist, or Palestinian point of view, even if this greater familiarity has not yet led to a recognition of its legitimacy or even validity.

\section{Theater and Films}

In his 1995 book, Dan Orian provides a comprehensive look at the image of "the Arab" in Israeli theater from its origins to the present. ${ }^{6}$ In most plays, Arabs are portrayed as shallow, one-dimensional figures, clearly the objects of the playwrights' hatred, fear, and hostility. Directors generally embellished the racist text on stage with "typical" Arab traits such as sloppy dress and lisping speech. These stereotypes have characterized plays since 1936 and have not been limited to right-wing theater people (most of whom in any case are on the Left).

A certain change in this monolithic approach appeared in the early 1970 s when a younger generation of playwrights and directors introduced pacifist ideas into their works. Hanoch Levin was among the first to critique Israel's militaristic society; the best known of his plays, a 1970 satirical cabaret entitled The Queen of the Bath which took on corruption in the army, was censored as soon as it appeared. ${ }^{7}$

Self-criticism in the theater, as in other artistic domains, was largely limited to post-1967 Israel and focused on the moral implications for the "democratic and just" Israeli Jewish society of continuing occupation of the West 
Bank and the Gaza Strip. This is not surprising, since many theater people identified with Peace Now and shared the movement's ambivalences discussed earlier in this series. The pattern is particularly clear in the so-called "Peace Now plays," which appeared following the Lebanon War. Thus, the Palestinians in the plays of Yehoshua Sobol or Benny Barabash remain enigmatic and cardboard figures playing secondary roles, while the fully developed Jewish heroes shoot, kill, and torture but then regret their actions. ${ }^{8}$

There is a non-Zionist approach in the theater, but it is marginal both in commercial terms and political effect. It appears either in translated Palestinian works or in original non-Zionist Israeli plays. One of the translated works was a Hebrew adaptation of Ghassan Kanafani's Men in the Sun. ${ }^{9}$ The play, which appeared on the local stage in 1989, was a commercial disaster but hinted at possible things to come. Original Hebrew works were more popular. For example, some of Sami Michael's stories were adapted for the stage, becoming the first plays to humanize Palestinians, endowing the traditionally shadowy figures with names, histories, and ambitions. In this context, one can also mention the appearance in the fringe theater of plays written by Palestinian Israelis depicting the occupation and the lives of Palestinians in Israel, as well as a 1994 binational coproduction in Jerusalem of a contemporary version of Romeo and Juliet. ${ }^{10}$

Yitzhak Laor, although primarily a poet, is one of the few Israelis who contributed to the stage in a direct non-Zionist fashion with his general critique of Israeli militarism. In contrast to the introversive Peace Now approach, Laor is less interested in what happens to Israeli society as a consequence of the occupation than in the suffering of the Palestinians themselves. His 1989 play Ephraim Hozer La-Zava (Ephrahim returns to the army), which includes realistic descriptions of Shin Bet interrogation and torture, was censored for a time because it made a connection between Nazi behavior and Israeli occupation policies. Sobol had made the same connection in satirical fashion in a 1984 cabaret called The Hanging Tree. A few other plays followed suit, but the Israeli public became more aware of the brutalization of Israeli military behavior only when the press was bold enough to expose the ugly side-for that matter the only side-of life in the shetahim, the Hebrew term for "territories" that is, significantly, ageographical and beyond a defined existence.

The film industry in Israel has gone through a similar process, but in many respects it has gone further than any other medium in presenting fundamental challenges to the Zionist historical narrative and discourse. Moreover, any change in approach to reality is far more significant in cinema insofar as it is one of the most popular pastimes in Israel, especially when one considers that Israel has an elaborate and expanding cable system that broadcasts commercial films on television about a year after they have been shown in movie houses.

It is interesting to note that the first changes in approach took place not on commercial movie screens but in television studios. This may be because 
national television directors in the 1970s, unlike their colleagues in the commercial or private film world, tended to be given a budget with which to work, and once they had it could give vent to the more radical views disproportionately represented in Israel's artistic community. Moreover, as long as there was only one state-owned television channel, considerable effort was invested in creating local drama, much of which is highly politicized. One of the first attempts to convey in film a different perception of reality was the director Ram Levi's 1976 screen adaptation of a famous story written by S. Yizhar after the 1948 war describing the maltreatment of an Arab prisoner; the fact that Yizhar situated the tragedy in an undefined fictional place must have made it easier for his readers and even himself to digest the possibility of Israeli soldiers committing atrocities. Levi made the story concrete, guiding viewers to its relevance for Israeli behavior toward Palestinians in the occupied territories. But the channel's executives, who apparently did not wish to shed an unpleasant light on the 1948 war, prevented the screening of this innovative film, Hirbet Hiza, even though the book in which the story appeared is considered part of the canonical literature. Levi continued to produce TV drama that would be shown in the 1980s, such as the $1986 \mathrm{Ani}$ Ahmad (I am Ahmad), which criticized the Israeli state's treatment of Israeli Palestinians.

Until the early 1970s, the film industry followed the nationalist agenda more closely than any other cultural agency except for children's books. It was thus that Arabs were depicted on the screen as pathetic stereotypical figures-evil, cruel, and stupid-who end up yielding to the superior Israeli hero. A common plot is one in which Jewish school children singlehandedly capture armed Arab terrorists or invaders. ${ }^{11}$ The Lebanon War had a catalytic effect on the cinema. Israeli filmmakers began to give a voice to underprivileged and deprived individuals and groups in Israel, though the transformation was limited to criticism of the Peace Now variety: None of the films deviated from the Zionist metanarrative or from the major chapters in the mythical historiography taught in the schools, but limited themselves to Israel's post-1967 Palestinian dilemma. Even so, and despite the fact that the filmmakers prefer to tell the story of the conflict through romance, this is an impressive development compared to the 1960s. The Palestinians have become real human beings and, at times, even heroes on the screen. ${ }^{12}$

Romance and sex sell, and romance has been the main sweetener for the new views offered to the filmgoers. Most of these films are modeled on a Romeo-and-Juliet-type plot: A Jewish women falls in love with a Palestinian man against the wishes of their respective families and societies. ${ }^{13}$ Such films can generate sensual identification with the heroes. As with Hollywood's films about deprived minorities, so in the "enlightened" Israeli film industry, the "Arabs" are exceptionally handsome or beautiful. The focus on sex and beauty permits what psychologists call displacement: Instead of identifying with the cause or the general suffering inflicted on the other side, the viewer identifies with the broken heart of an attractive hero. 
Still, these films, where Jews appear as villains and Palestinians as heroes, do have an effect. Switching conventional roles challenges the image of the Arab in the Zionist metanarrative. No academic work could reach such a broad audience or produce such a clear message. One of these films, the 1989 Esh Zolvet (Crossfire), went beyond the gender subject and presented, in a way that has never again been seen in Israeli fictional film, a Palestinian perspective of the 1948 war. For example, the film, which proved to be a commercial failure, showed the despair and bewilderment of the Palestinians when they learned about the 1947 partition resolution, whereas usually they are shown rejoicing at the opportunity to shed blood. ${ }^{14}$

In the late 1980s and early 1990s, the film industry underwent a genuine process of radicalization. Films have become the avant-garde in the local Jewish attempt to reassess the essence of Zionism. The background for this radicalization, as in academia, is sociopolitical: The cumulative impact of the intifada and Israel's relative isolation before the 1992 elections brought Labor back to center stage. Selling is the key word for cinema, as it is for culture in general, and it seems that critiques of Zionism can sell. Although the political messages are shaped and at times constrained by commercial considerations, it is precisely the fact that a film with a radical message can be relatively profita-

The fact that a film with a radical message can be profitable shows that, at least in the arts, being a non-Zionist is possible. ble that shows that, at least in the arts, being a nonZionist is possible and hence more than a passing fashion. This is a serious development, parallel to the contradictory process of insularity led by religious fanaticism and extreme nationalism; these two processes increasingly are polarizing Israeli society.

Compared to the academics, the filmmakers appear to be more open about their own ethnic, gender, or national "agendas," which they discuss in interviews and seminars following film screenings as well as in some of the dialogues or scripts. Films for the first time represent the world of Israel's Arab Jews, whose socioeconomic status has improved in only limited fashion since 1948. The films portray their growing frustration with the prospering Ashkenazi upper classes, their geographical and social marginality in the development towns and peripheral slums, their limited access to financial resources, and their distorted image in the national narrative. ${ }^{15}$ Some of the filmmakers who portray Sephardic life have also dealt with Palestinians. Ram Levi, for example, whose above-mentioned films Hirbet Hiza and Ani Ahmad are concerned with Palestinians, deals with the development towns in a 1985 film called Lehem (Bread).

For all the radicalism in this new wave cinema, Ashkenazi predominance is still apparent. Most of the films that could be classified as having a non- or even anti-Zionist stance depict the Arab-Jewish relationship in Israel from the perspective of yuppies in Tel Aviv. Because their agenda is political rather than social, these films can appeal to those living in relative comfort, who can afford to identify with the "other"; one wonders how they are re- 
ceived by mass audiences in the more deprived areas. (They are, of course, accepted warmly by Israel's Palestinians and in that sense strengthen ArabJewish cooperation.) That some of the films depicting the Israeli as an occupier and colonizer and the Palestinian as victim have been shown for several weeks is an indication that they are intriguing enough to create empathy or at least interest. ${ }^{16} \mathrm{Jad}$ Ne'eman, who made a film challenging Zionist truisms ${ }^{17}$ and who writes on the ideological implications of films, has commented that the recent films convey through their texts and subtexts a radical criticism of Zionism.

Yet despite these impressive forays into other perspectives, the treatment of the "other" in films and plays is inhibited by the projection of an Israeli image onto the Palestinian-it is as if the other side can be understood only if its heroes act like Israelis or subscribe to an Israeli concept of reality. ${ }^{18}$ For instance, in the film Avanti Popolo, an Egyptian soldier conveys the message of human values common to both sides by quoting Shakespeare's Shylock.

Still, Israel's fictional film industry has proven to be the boldest medium in exposing sensitive dilemmas and taboos. A few films went so far as to take on the manipulation of the Holocaust in Israeli politics and discourse. Ilan Moshenson's 1979 movie Roveh Huliot (A toy gun), for example, conveys the Israeli uneasiness over the possible link between the Nazi wish to annihilate the Jews in Europe and the Zionist desire to see the expulsion of Jews from Europe for the sake of the Jewish community in Palestine. Some of these same themes have been treated in television docudramas. Moti Lerner's 1995 made-for-television movie Kastener, for example, is based on the true story of a Zionist activist who saved Hungarian Jews by bribing Nazis and was later brought to trial in Israel; the film highlighted the uneasy connection between the Jewish leadership in Palestine and the Holocaust and conveyed the idea that the survival of the community in Palestine always came first. A docudrama by Benny Brunner based on Tom Segev's book The Seventh Million, shown in 1995, focused on the Jewish leadership's decision not to become involved in operations to save Jews that did not bring survivors to Palestine and to concentrate on efforts to save Jews who were physically and mentally fit and likely to contribute to nation building.

Most documentary films, on the other hand, tend to be more inhibited. Made mainly for national television, they tend to be particularly faithful to the official line: Although documentaries shown on television require scholarly consultation, most of the consultants are mainstream. The lack of empathy for the other side is evident when pictures of Palestinian refugees are shown: The running commentary does not disclose even a modicum of compassion, and the word "refugee" hardly ever is mentioned. ${ }^{19}$

A few documentary filmmakers, both Jewish and Palestinian Israelis, have explored issues that contradict the main Zionist narrative. Among these, Amos Gitai stands out as exceptional. His 1980 film Bayt (House) tells the story of a house in Jerusalem undergoing restoration. The house had belonged to a Palestinian doctor in 1948 but was confiscated by the Israelis and 
sold to Jewish immigrants from Algiers. The house, usually a symbol of security, becomes a symbol of conflict. Although Gitai's film does not question the Algerian family's legitimacy, it fully recognizes the legitimacy of the Palestinian claim. Similar themes can be discerned in Gitai's later films.

Among Palestinian filmmakers, Nizar Hasan effectively conveys the national identity of Arabs living in Israel. His Istiqlal, in Arabic with Hebrew subtitles, tells the story of a village in Israel that has remained Palestinian despite coercion, denial, co-optation, and confiscation. For the Israeli Jewish public, however, it is the "discovery" of past Israeli "sins" that potentially has the greatest impact on attitudes. One powerful film is David Ben Shitrit's 1992 documentary, Meb'ad le-Re'alat Ha-Galut (Behind the veil of exile), which follows the lives of three Palestinian women from a perspective totally based on the Palestinian historical narrative. It may be the only time Israeli trucks loaded with expelled Palestinians have ever been shown on Israeli television.

\section{Impact and Significance of The New Discourse}

It is not easy to assess the possible impact on Israeli society of the new post-Zionist orientations in the various cultural products. Thus, even though the Israeli press in general is widely read, there is no way of knowing how extensively the post-Zionist debate has been followed by the mass public. Poetry and literature, as we have noted, probably reach only a limited group of people. In contrast, the film industry is the most popular cultural medium in Israel. Whether made for cinema or television, films have the greatest potential for influencing public opinion toward a more critical view of Zionism and in conveying more positive images of the "other" (Arabs).

In general, it would be fair to say that the novels, plays, and films that have seriously transcended the Zionist narrative and its negative portrayal of Arabs have not been accepted as part of the Israeli canon. They do not represent a dominant cultural position, and their producers are not among the leaders of the Israeli cultural scene. Nonetheless, the "new historians," poets, writers, filmmakers, and playwrights are within the system that produces and shapes the cultural identity, and they have some effect, albeit limited.

The scholarly debate continues, with other cultural producers joining in. The debate signals not only a scholarly rift, but an identity crisis in a society that was exposed to the possibility of peace in 1993. Peace has the potential of undermining the national consensus based on the need to act jointly against common enemies. Relative economic success and security already has led deprived groups to demand their share, just as it has encouraged the Palestinians in Israel to lay bare the insoluble tension between the country's pretention to be a democracy and its insistence on remaining a Jewish state. Genuine peace demands a radical change in the Israeli mentality and in basic Jewish views about Arabs in general and Palestinians in particular. The significance of the phenomena described above is that a small number of 
people with access to the public via the universities, schools, press, and movie screens have begun to offer starting points for such a transformation. The point of departure is acknowledgment that reality can be interpreted in a non-Zionist way, or at least that Israel's cultural identity must be more pluralistic.

The cultural identity of a society is shaped by historical and contemporary reality on the one hand and by how this reality is interpreted by those who control sociopolitical power on the other. Israel's cultural identity in 1997 can be summed up as a cultural product shaped by the heritage and human geography of the land of Palestine and by the conscious national (i.e., Zionist) attempt to change the identity of that land. From the very beginning, Zionism rejected the Palestinian identity of Palestine and successfully used forceful means to Judaize it. However, there are challengers to the Zionist identity: Palestinians, some of the Jews brought from Arab countries, and a small number of individuals, such as this writer, who were born in the country after the state's establishment and now voice dissent.

The Zionist identity of the land and society is undermined not because of "new historians" or anti-Zionist novelists. The political demands of deprived groups, the continuing occupation of the West Bank and Gaza Strip, and the frozen peace process all contribute to a process that will turn Zionism either into an anachronism or a concept that can be implemented only through an aggressive policy such as the one adopted by the settlers. These processes began in 1977 when the hegemony of the Ashkenazi political elite was challenged, continued with the 1982 Lebanon War and the intifada, and culminated with Rabin's assassination and the May 1996 elections.

Even before these dramas occurred, however, the influx of Jews from Arab countries gave society a "Middle Eastern" cultural identity. Forceful efforts were made in the name of cultural homogenization to eradicate this culture from the first generation of Sepharadim: It was thus that all elements of Arab culture, including language, were portrayed in the schools as inferior, and the young generation was encouraged to forget their mother tongue and become "Israeli," i.e., Ashkenazi. Still, these buried roots come to the fore in a longing for things Arab and in the Arabic music heard in the development towns, in literature, poetry, and politics-though this longing often coexists with anti-Arab racism in an absurd mix that is nourished by the Ashkenazi-dominated political parties in power. If these urges for an authentic cultural identity are ever freed from the nationalist interpretation of reality, they could serve as a potent force for de-Zionizing Israel.

\section{Notes}

1. Dalia Rabikovitch's poem, "To Leave Beirut," described the war from the Lebanese point of view.

2. Yerach Gover, Zionism: The Limits of Moral Discourse in Israeli Hebrew Fic- tion (Minneapolis: University of Minnesota Press, 1994). In Ballas's A Locked Room (Jerusalem: Zemora Bitan, 1982), the protagonist is a Palestinian Israeli who is a member of the Communist 
party. In The Other One Jerusalem: Zemora Bitan, 1991), Ballas presents Zionism as it is perceived from an Arab nationalist perspective.

3. Albert Swisa, Aqud (Bound) (Tel Aviv: HaKibbutz HaMeuhad, 1985).

4. Yitzhak Laor, The People, Food Fit for a King (Tel Aviv: Hakibbutz HaMeuhad, 1994).

5. David Grossman, Nochaim Nifkadim (Present absentees; titled "Sleeping on a Wire" in an English edition) (Tel Aviv: HaKibbutz HaMeuhad, 1992) and HaZeman Ha-Zahov (The yellow time) (Tel Aviv: HaKibbutz HaMeuhad, 1987).

6. Dan Orian, The Arab in Israeli Theater (Jerusalem: Or-Am, 1995) (Hebrew).

7. The Hebrew title of this Hanoch Levin play is MalKat Hambatia.

8. Typical plays that present the "Peace Now dilemma" are Benny Barabash, Ehad Meshelanu (One of us), 1988, and Yehoshua Sobol, HaFalestinait (The Palestinian woman), 1985.

9. For an analysis of this adaptation and other plays based on Kanafani's work, see my "A Text in the Eyes of the Beholder: Four Theatrical Interpretations of Kanafani's Men in the Sun," in Contemporary Theater Review 3-2 (1995), pp. 157-74.

10. Fuad Awad and Eran Baniel codirected Romeo and Juliet for Han (an Israeli Jerusalemite theater) and al-Qasaba (a Palestinian Jerusalemite theater).

11. At the beginning of November 1996, Daniel Bartal, of the School of Education at Tel Aviv University, issued a survey showing that in most Israeli textbooks throughout the educational system, Arabs are depicted as "murders," "villains," "blood suckers," and so on.
12. The most successful commercial film which used this exchange of roles is Uri Barabash's 1984 Meahorei HaSoragim (Behind the bars), in which a Palestinian political prisoner leads a prison revolt. Starting from the 1980s, a number of films have featured Arabs as heroes.

13. Hamsin, about a love affair between a Palestinian day laborer and the daughter of his employer, was the most famous of this genre.

14. Esh Zolvet was directed by Gideon Ganani, with screenplay by Benny Barabash.

15. See further Jad Ne'eman, "The Empty Tomb in the Postmodern Pyramid: Israeli Cinema in the 1980s and 1990s," in Documenting Israel, ed. C. Berlin (Cambridge: Harvard University Press, 1993), pp. 1-20.

16. One such film was Gesher Zar Meod (A very narrow bridge), directed by Nissim Dayan and released in 1985.

17. Ne'eman's film, released in 1977 , is Masa Alunkot (a term used to describe one of the most challenging military exercises new Israeli soldiers undergo at the beginning of their army training).

18. The idea of appropriation is brought in Laor's book, Anachnu (We are writing in your service, homeland) (Tel Aviv: Kibbutz Meuhad, 1995).

19. It is interesting to note that in 1988 , mainstream historians assisted in producing a propaganda version of the 1948 war called Ohalei Ha-palmach (The tents of the Palmach), directed by Gil Sadan. A year later a more critical director, Nissim Dayan, used more revisionist consultants and produced a more balanced film with the same title. 